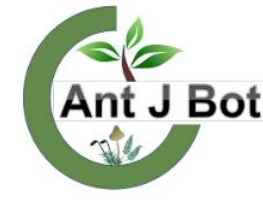

Received : 27.07.2020 Accepted : 15.10 .2020 Online : $: 26.10 .2020$

\title{
Morpho-anatomical and phytochemical evaluation of Icacina trichantha Oliver (Icacinaceae)
}

\author{
Akeem Babalola KADIRI ${ }^{*}{ }^{\circ}$, Taiwo Olayinka ASEKUN ${ }^{\circ}$, Anita Kelechi ASEKUNOWO ${ }^{\circ}$, \\ Emmanuel Abiodun AYODELE ${ }^{4}$, James Dele OLOWOKUDEJO5 ${ }^{\circ}$ \\ ${ }^{1}$ Lagos University, Department of Botany, Akoka Yaba Lagos, Nigeria \\ ${ }^{2,3}$ Lagos University, Department of Chemistry, Akoka Yaba Lagos, Nigeria \\ ${ }^{4,5}$ Ibadan University, Department of Botany, Ibadan, Nigeria \\ *abkadiri2001@yahoo.com, ${ }^{2}$ oasekun@unilag.edu.ng, ${ }^{3}$ aasekunowo@unilag.edu.ng, ${ }^{4}$ bayodele@yahoo.com, \\ 5olowokudejo@gmail.com
}

\section{Icacina trichantha Oliver'in (Icacinaceae) morfo-anatomik ve fitokimyasal değerlendirmesi}

\begin{abstract}
The leaf epidermis of Icacina trichantha, a quintessential medicinal tropical plant was investigated with the aid of light microscopy and the chemical constituents of its leaf and root were investigated using Gas Chromatography-Mass Spectrometry (GC-MS). Hitherto, leaf epidermis data is missing and similarly, the chemical analysis of the leaf and root of the plant is undertaken in a single study for the first time. The leaf epidermis characters with which the species can be defined include paracytic and diacytic stomatal types, irregular epidermal cell shape together with angular or curved anticlinal wall patterns. However, the quantitative data appeared to overlap thus providing the range of values of both the measured and counted features. N-hexane extract of the root is rich in reducing sugars, tannins, steroids, glycosides, terpenoids and flavonoids while GC-MS analysis revealed 11 and 3 significant esterified bioactive components in the leaf and tuberous root respectively with dodecanoic acid being most abundantly present (47.85\%-54.10\%) but some chemical confined to specific areas are trichothec-9-en-8-one $(47.73 \%)$ in the root and 9-octadecenoic acid $(25.05 \%)$ in the leaf. The result of this study will assist in identifying the plant even if its parts are fragmentary and also be helpful in screening the plant for drug.
\end{abstract}

Key words: Microscopy, taxonomy, tropical plant

\begin{abstract}
Özet: Önemli bir tıbbi tropik bitki olan Icacina trichantha'nın yaprak epidermisi ışık mikroskobu yardımıyla, yaprağının ve kökünün kimyasal bileşenleri de Gaz Kromatografisi-Kütle Spektrometresi (GC-MS) kullanılarak incelenmiştir. Halihazırda bitkinin yaprak epidermis verileri eksik durumdadır ve bitkinin yaprağı ve kökünün kimyasal analizi tek bir çalışmada ilk kez yapılmıştır. Parasitik ve diasitik stoma tipleri, düzensiz epidermal hücre şekli ve köşeli veya kavisli antiklinal duvar desenleri türün tanımlanmasında kullanılabilen yaprak epidermis karakterleri arasında yer alır. Bununla birlikte, nicel veriler, hem ölçülen hem de sayılan özelliklerin değer aralığını sağlayacak şekilde örtüşür nitelikte görümektedir. Kökün N-heksan ekstresi indirgeyici şekerler, tanenler, steroidler, glikozitler, terpenoidler ve flavonoidler bakımından zengindir; GC-MS analizi de yaprak ve yumrulu kökte, en yaygını dodekanoik asit (\%47.85 - \%54.10) olan, sırasıyla 11 ve 3 önemli esterlenmiş biyoaktif bileșen ortaya çıarmıștır. Buna karșın bazı kimyasalların belirli bölgelerle sınırlı (kökte trichothec-9-en-8-one, \%47.73, yaprakta 9-oktadekenoik asit, \%25.05) kaldığ görülmüştür. Çalışma bulguları, bitki bir bütün halinde olmasa bile bitkinin teşhisine katkı sağlayacaktır ve bitkinin drog olarak taranmasında da yardımcı olacaktır.
\end{abstract}

Anahtar Kelimeler: Mikroskopi, taksonomi, tropik bitki

Citation: Kadiri AB, Asekun TO, Asekunowo AK, Ayodele EA, Olowokudejo JD (2020). Morpho-anatomical and phytochemica evaluation of Icacina trichantha Oliver (Icacinaceae). Anatolian Journal of Botany 4(2): 100-105.

\section{Introduction}

Icacina trichantha Oliver belongs to the family Icacinaceae (Hassler, 2020). It is one of the five species (Icacina claessensii De Wild., I. guessfeldtii Asch. ex Engl. I. mannii Oliv., I. oliviformis (Poir.) J.Raynal and I. trichantha Oliv.) of the genus and are found only in Africa. The plant is a perennial shrub up to $2 \mathrm{~m}$ with scandent growth above, and commonly found in crop fields, forest regrowths and waste areas in the forest and savannah. The leaves are broadly elliptic, abruptly acute at the apex and rounded at the base. Sometimes, they may be thinly pilose with simple, fascicled hairs beneath. Leaf length is about $8.0-10.0 \mathrm{~cm}$. while the width is up to 17.0 $\mathrm{cm}$. Flowers are densely crowded and subsessile with calyx nearly as long as the petals which are usually villous outside. The fruits are tomentose on the surface, ellipsoid to globose in shape and they are about $2.5 \mathrm{~cm}$ long (Hutchinson and Dalziel, 1958; Agyakwa and Akobundu, 1998). It is sometimes locally abundant and troublesome as a weed in some parts of Nigeria. It is called as "Gbegbe" in Yoruba in the south west Nigeria and "Ibugo" in Igbo in the eastern Nigeria (Burkhill, 1985). The plant is extensively used in the rural areas; the leaves and tuber have folkloric uses in the treatment of malaria, constipation and food poisoning in Nigeria (Asuzu and Abubakar, 1995a; Che et al., 2016).

Phytochemicals are secondary metabolites from plants that are responsible for their medicinal properties. The presence of phytochemicals such as flavonoids, terpenoids, tannins, glycosides, reducing sugars, steroids have been reported in different extracts and parts of $I$. trichantha (Onakpa et al., 2014; Otun et al., 2015). These phytochemicals may be responsible for the antihyperglycemic, anticonvulsion, sedative, analgesic, and antimicrobial properties ascribed to the plant (Dalziel, 1937; Burkill, 1985; Asuzu and Abubakar, 1995b; Asuzu and Aforonwa, 2008; Onakpa and Asuzu, 2013; Onakpa et al., 2014; Alawode et al., 2018). 
In this investigation, the phytochemical composition of hexane extract of leaf and root using preliminary screening and GC-MS analysis was carried out in a single study for the first time, in addition to the micromorphological evaluation of the leaf epidermis which has not been studied before. Leaf epidermal characteristics are well known to offer useful identification criteria for plants, as well as chemical characters, which also can be used to define their pharmacological usefulness. These two studied character sources of the plants (anatomy and chemistry) are important data sources for species identification and utilization of the plant as a source of drug

\section{Materials and Method}

Fresh samples of I. trichantha were collected from different locations across Southern Nigeria (Fig. 1), and the samples were dried and authenticated at the Lagos University Herbarium (LUH). Herbarium abbreviation follows Holmgren and Holmgren (2003). The leaves and roots were both used for the study. The former was mainly used for micro-morphological assessment, and 100 leaf samples obtained from all the individuals collected were investigated. However, the dried leaves and roots were pulverized and kept in ziplock for further investigation of chemical analysis and phytochemical screening.

For micro-morphological evaluation of the leaves, the study approach of Stace (1965), Kadiri et al. (2003), Kadiri and Olowokudejo (2016) and Ogundipe and Akinrinlade (1998) was followed while for phytochemistry, the method of Ajayi et al. (2011), Harborne (1991) and Trease and Evans (1998) was adopted.

\subsection{Epidermal peel (leaf epidermis)}

For the study, a light microscope was used. The acid soaking and counter-staining method which has proven useful for obtaining leaf epidermis from many African plants was adopted, following the approaches of Ogundipe and Akinrinlade (1998) and Kadiri and Olowokudejo (2016) with some modifications. Leaf portions of $2-3 \mathrm{~cm}^{2}$ were cut from the standard median portion of the leaf lamina near the mid-rib, boiled in water for 30 minutes, and then soaked in concentrated nitric acid $\left(\mathrm{HNO}_{3}\right)$ in capped specimen bottles for two to four hours to macerate the mesophyll tissue. Tissue disintegration was indicated by air bubbles, the stage at which the leaf tissues were transferred into Petri dishes containing water for separation of the epidermis using a pair of forceps and mounting needle. Tissue debris was cleared off the epidermis with an artist's fine-hair brush and washed in several changes of water. Two to three drops of sodium hypochlorite solution were dropped onto the epidermis on the slide to bleach opaque areas and allowed to soak for 30-120 seconds until a color change. The epidermis peel was mounted on the slide and then two to five drops of ethyl alcohol in a series of ascending concentrations (50\%, $75 \%$, and $100 \%$ ) were added to harden the cell wall. Two to three drops of $10 \%$ aqueous Methylene Blue and one drop of $50 \%$ aqueous Safranin were later added for three to five minutes. One to two drops of glycerine were added, then the preparation was covered with a transparent coverslip and the edges were sealed with nail polish to prevent dehydration. Each slide was observed under magnifications of $\times 100$ and $\times 400$ so as to capture all the features of the epidermis. These features were recorded qualitatively, and basic statistical calculations were made to show means, standard error and ranges of variations. Photomicrographs were taken using an Olympus microscope with an attached camera.

Stomata index (SI) was calculated using the formula of Stace (1965).

Stomata index $=\frac{\text { Stomata number }}{\text { cell number per unit area }+ \text { stomata number }} \times 100$

\subsection{Extraction of plant material}

The pulverized leaf and root sample (10 g) of Icacina trichantha was separately extracted using Soxhlet apparatus and hexane as solvent. The hexane solvent (250 $\mathrm{ml}$ ) was put in a round bottom flask, attached to a Soxhlet extractor and condenser on an isomantle. The pulverized sample was loaded into the Soxhlet thimble and the side arm lagged with glass wool. As the hexane was heated via the isomantle, it evaporated, condensed then dripped into the reservoir containing the thimble. The solvent flows back into the flask once its level reaches the siphon it pours back and the cycle was repeated several times for a period of $9 \mathrm{hr}$. The non-volatile extract obtained from the plant was obtained and kept in a sterile vile and stored at 4 ${ }^{\circ} \mathrm{C}$ for phytochemical investigations.

\subsection{Phytochemical screening}

The preliminary phytochemical screening of the hexane root extract was carried out by physical observation of colour change. The following phytochemicals viz: alkaloid, saponin, flavonoid, anthraquinone, glycoside, tannins, steroid, protein and volatile were investigated using standard protocols (Trease and Evans, 1989; Sofowora, 1993; Harborne, 1999).

\subsection{GC-MS analysis}

Gas Chromatography-Mass Spectrometry (GC-MS) of both leaves and root hexane extracts were also carried out at the University of Lagos Central Research Laboratory, Nigeria. The model of the GC-MS used for mass spectral identification of the hexane extracts of the leaves and root of I. trichantha was an Agilent 6890 interfaced to a 5973 mass selective detector. The capillary column $(30 \mathrm{~m} \mathrm{x}$ $0.25 \mathrm{~mm} \times 0.25 \mu \mathrm{m}$ film thickness) was HP-5MS. The oven temperature of $50^{\circ} \mathrm{C}$ for 5 minutes was firstly maintained and then set to $250{ }^{\circ} \mathrm{C}$ at $5{ }^{\circ} \mathrm{C} \min ^{-1}$. Helium (99.999\%) was the carrier gas used at a flow rate of $1 \mathrm{ml} /$ min, and $1 \mu 1$ injection volume was employed (split ratio of 10:1). The electron-impact ionization mass spectrometry electron energy of $70 \mathrm{eV}$ of was operated at an. Mass spectra were taken at $70 \mathrm{eV}$, a scan interval of 0.5 seconds and fragments from 40 to $450 \mathrm{Da}$. The total GC running time was $45 \mathrm{~min}$. The spectra data obtained were compared with those of NIST library mass spectra.

\section{Results}

Detailed variations in the qualitative and quantitative characters of the leaf epidermis of Icacina trichantha are shown in Table 1. The leaf is hypostomatic and the stomatal types are paracytic and diacytic (Fig. 1B, Table $1)$. The epidermal cell shape is irregular on both surfaces of the leaf (Fig. 1A, B; Table 1) but the anticlinal wall pattern is either angular on the adaxial surface or curved 


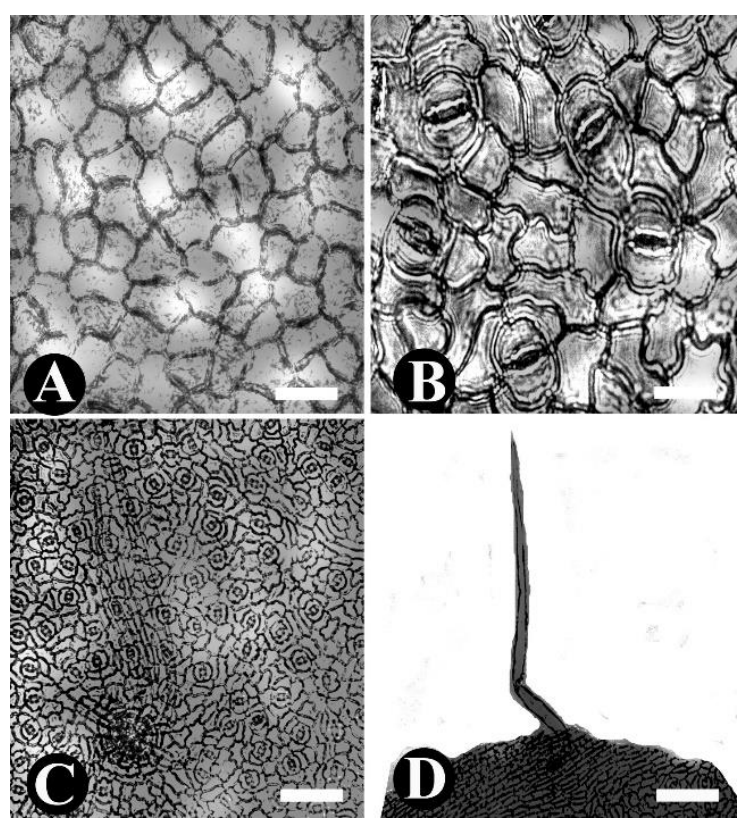

Figure 1. Leaf epidermis features of Icacina trichantha. A: Adaxial surface, B-D: Abaxial surface, D: Typical unicellular trichome found on the abaxial surface of the leaf. Scale bar = $40 \mu \mathrm{m}$.

on the abaxial surface of the epidermis (Fig. 1, Table 1). Both the non-stomatal and stomatal quantitative features reasonably overlap across the one hundred leaf samples that were investigated (Table 1).

The result of the phytochemical analysis from this study is as presented (Fig. 2, Table 2). The hexane extract of the root of I. trichantha is rich in reducing sugars, tannins, steroids, glycoside, terpenoids and flavonoids, while saponins, alkaloid, anthraquinone and the volatile oil is absent. GC-MS analysis of n-hexane extracts of both the leaf and the root of I. trichantha were reported (Table 3). Eleven significant bioactive components were found in the leaf while the root revealed 3 bioactive components in high percentage concentration. Dodecanoic acid was revealed to be the major component in both extracts with the leaf $(54.10 \%)$ having a higher concentration than the

Table 1. Qualitative and quantitative characteristics of the leaf epidermis of Icacina trichantha

\begin{tabular}{|l|c|c|}
\hline \multirow{2}{*}{ Features } & \multicolumn{2}{|c|}{ Surfaces } \\
\cline { 2 - 3 } & Adaxial surface & Abaxial surface \\
\hline Cell shape & Irregular & Irregular \\
\hline Wall pattern & Angular & Curved \\
\hline E. cell No./ field & 56 & 68 \\
\hline E. cell length $(\mu \mathrm{m})$ & $28.0(42.0 \pm 2.0) 58.5$ & $30.0(48.0 \pm 2.0) 65.2$ \\
\hline E. cell width $(\mu \mathrm{m})$ & $12.0(15.0 \pm 2.0) 25.3$ & $10.5(12.0 \pm 2.0) 16.0$ \\
\hline Stomata & Absent & Present \\
\hline Stomata No./ field & Absent & 42 \\
\hline Stomatal type & Absent & Paracytic, diacytic \\
\hline $\begin{array}{l}\text { Stomatal length } \\
(\mu \mathrm{m})\end{array}$ & Absent & $22.0(27.0 \pm 2.0) 30.0$ \\
\hline $\begin{array}{l}\text { Stomatal width } \\
(\mu \mathrm{m})\end{array}$ & Absent & $8.5(10.0 \pm 2.0) 12.0$ \\
\hline Stomatal index $(\%)$ & Absent & 38.2 \\
\hline Trichome & Absent & $\begin{array}{c}\text { Long unicellular } \\
\text { trichomes present }\end{array}$ \\
\hline
\end{tabular}
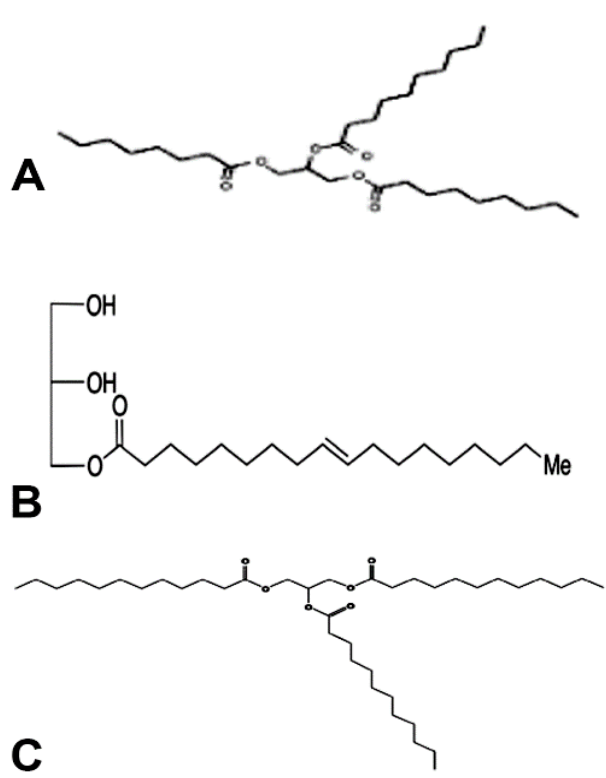

Figure 2. Structures of some of the chemicals found in $I$. trichantha A: 9-Octadecadienoic, B: Methoxyacetic acid, C: Dodecanoic acid and B were found in the leaf while C occurred in the root.

root $(47.85 \%)$. The root in addition revealed the presence of Trichothec-9-en-8-one $(47.73 \%)$. The leaf extract also revealed 9-Octadecenoic acid $(25.05 \%)$. Other prominent components in the leaf extract were acetamide $(6.21 \%)$ and methoxyacetic acid (5.58\%) (Table 3).

\section{Discussions}

A combined evaluation of the leaf epidermis and chemical features of I. trichantha carried out in the study has shown that the documented characters are useful for identification. They are also potentially suitable for differentiating the species from any other related species in the family Icacinaceae. Those features that seem to be good for defining the species include hypostomatic leaves, paracytic and diacytic stomatal types, and the presence of simple unicellular trichomes which are usually restricted to the abaxial surface of the leaf. However, the taxonomic relevance of epidermal features has been expounded by several workers, as being good for identification, delineation, classification and in resolving taxonomic intricacies (Davis and Heywood, 1963; Stace, 1965;

Table 2. Phytochemical analysis of the tuberous root of Icacina trichantha

\begin{tabular}{|l|c|}
\hline Phytochemical & Result \\
\hline Reducing sugars & + \\
\hline Tannins & + \\
\hline Saponin & - \\
\hline Alkaloids & - \\
\hline Steroids & + \\
\hline Glycoside & + \\
\hline Flavonoids & + \\
\hline Anthraquinone & - \\
\hline Terpenoids & + \\
\hline Volatile oils & - \\
\hline Proteins & - \\
\hline Key: $+=$ present, $-=$ absent &
\end{tabular}


Table 3. Chemical composition of leaf and root of Icacina trichantha as revealed by Gas Chromatography-Mass Spectrometry (GC-MS)

\begin{tabular}{|c|c|c|c|c|}
\hline $\mathrm{S} / \mathrm{N}$ & Chemicals & $\begin{array}{l}\text { Concentration in } \\
\text { leaf }(\%)\end{array}$ & Chemicals & $\begin{array}{l}\text { Concentration in } \\
\text { root }(\%)\end{array}$ \\
\hline 1 & $\begin{array}{l}\text { Carbonic acid, octadecyl vinyl ester, } \\
\text { Carbonic acid, octadecyl prop-1-en -2-yl ester }\end{array}$ & $0.362 \%-0.433 \%$ & $\begin{array}{l}\text { Dodecanoic acid, 1,2,3-propanetriyl } \\
\text { ester, Trichothec-9-en-8-one, 12,13- } \\
\text { epoxy-3,7,15-trihydroxy-ester, } \\
\text { monoacetate, (3.alpha.,7.alpha.)-ester, } \\
\text { Dodecanoic acid, 1-(hydroxymethyl)- } \\
\text { 1,2-ethanediyl ester }\end{array}$ & $28.211 \%-83.84 \%$ \\
\hline 2 & Sulfurous acid, 2-propyl tetradecyl ester & $0.366 \%-0.70 \%-$ & $\begin{array}{l}\text { Dodecanoic acid, 1,2,3-propanetriyl } \\
\text { ester, Cyclododecanol, 1- } \\
\text { aminomethyl-ester }\end{array}$ & $19.642 \%-58.37 \%$ \\
\hline 3 & Octacosane, Octadecane, 3-Eicosene esters & $0.616 \%-1.19 \%$ & $\begin{array}{l}\text { Trichothec-9-en-8-one, 12,13-epoxy- } \\
\text { 3,7,15-trihydroxy-, monoacetate, } \\
\text { (3.alpha.,7.alpha.)-ester }\end{array}$ & $33.650 \%-100.00 \%$ \\
\hline 4 & Heptacosane, 1-chloro-, Tritetracontane ester & $0.756 \%-1.46 \%$ & $\begin{array}{l}\text { Trichothec-9-en-8-one, 12,13-epoxy- } \\
\text { 3,7,15-trihydroxy-, monoacetate, } \\
\text { (3.alpha.,7.alpha.)-ester, Trimyristin }\end{array}$ & $14.086 \%-41.86 \%$ \\
\hline 5 & Hexadecane, 1-iodo-, Docosane, 9-octyl- ester & $0.835 \%-1.61 \%$ & $\begin{array}{l}(2 \mathrm{R}, 3 \mathrm{R}, 4 \mathrm{aR}, 5 \mathrm{~S}, 8 \mathrm{aS})-2-\mathrm{H} y d r o x y-4 \mathrm{a}, 5- \\
\text { dimethyl-3-(prop-1-en-2- } \\
\text { yl)octahydronaphthalen-1(2H)-one } \\
\text { ester }\end{array}$ & $4.411 \%-13.11 \%$ \\
\hline 6 & Tritetracontane ester & $0.698 \%-1.35 \%$ & - & - \\
\hline 7 & $\begin{array}{l}\text { Oleic Acid, Dodecanoic acid, 2,3-dihydroxyprop yl } \\
\text { ester, Methyl nonyl ether }\end{array}$ & $2.197 \%-4.23 \%$ & - & - \\
\hline 8 & Heptadecane, Docosane, 1,22-dibromo- ester & $0.698 \%-1.35 \%$ & - & - \\
\hline 9 & $\begin{array}{l}\text { Methoxyacetic acid, tridecyl ester, Diethylene glycol } \\
\text { monododecyl ether, Cyclohexane, 1R-acetamido-2,3- } \\
\text { cis- epoxy-4-cis-formyloxy-ester }\end{array}$ & $1.577 \%-3.04 \%$ & - & - \\
\hline 10 & $\begin{array}{l}\text { Cyclohexane, 1,1'-(2-propyl-1,3-propanediyl)bis-ester, } \\
\text { Cyclohexanol, 2-(2-propynyloxy)-trans-ester, } \\
\text { Cyclohexanol, 2-(2-propynyloxy)- 2-Dodecanol ester }\end{array}$ & $1.140 \%-2.20 \%$ & - & - \\
\hline 11 & $\begin{array}{l}\text { 9-Octadecenoic acid, Hexadecanoic acid, 2-hydroxy-, } \\
\text { methyl ester, 9-Octadecenoic acid (Z)-, octadecyl ester }\end{array}$ & $5.038 \%-9.70 \%$ & - & - \\
\hline 12 & $\begin{array}{l}\text { 9-Octadecenoic acid (Z)-, 2-hydroxy-1- } \\
\text { hydroxymethyl)ethyl ester, 2-Butoxyethyl oleate, Oleic } \\
\text { acid, 3-hydroxypropyl ester }\end{array}$ & $1.077 \%-2.07 \%$ & - & - \\
\hline 13 & 9-Octadecenoic acid (Z)-, 2,3-dihydroxypropyl ester & $3.089 \%-5.95 \%$ & - & - \\
\hline 14 & $\begin{array}{l}\text { Cyclohexane, 1R-acetamido-2,3-cis-epoxy-4-cis- } \\
\text { formyloxy-ester, Propanamide, N-(3-methoxyphenyl)- } \\
\text { 2,2-dimethyl-ester, Cyclohexanone, 2-(2-propenyl)- } \\
\text { ester }\end{array}$ & $0.292 \%-0.56 \%$ & - & - \\
\hline 15 & $\begin{array}{l}\text { 2-Methyltriacontane ester, Methoxyacetic acid, decyl } \\
\text { ester }\end{array}$ & $1.280 \%-2.47 \%$ & - & - \\
\hline 16 & $\begin{array}{l}\text { 9-Octadecenoic acid (Z)-, 2,3-dihydroxypropyl ester, } \\
\text { 9-Octadecenoic acid (Z)-, 2-hydroxy-1- } \\
\text { (hydroxymethyl)ethyl ester, Oleoyl chloride } \\
\end{array}$ & $\begin{array}{l}15.838 \%- \\
30.51 \%\end{array}$ & - & - \\
\hline 17 & $\begin{array}{l}\text { Acetamide, 2-chloro-N-(2-cyanoethyl)-ester, 2- } \\
\text { Dodecanol, 3-Heptafluorobutyroxydodecane }\end{array}$ & $6.214 \%-11.97 \%$ & - & - \\
\hline 18 & $\begin{array}{l}\text { 1-Methoxy-3-hydroxymethylheptane, Cyclobutanone, } \\
\text { oxime, Methoxyacetic acid, 2-tridecyl ester }\end{array}$ & $5.577 \%-10.74 \%$ & - & - \\
\hline 19 & $\begin{array}{l}\text { Dodecanoic acid, 1,2,3-propanetriyl ester, Dodecanoic } \\
\text { acid, 1,2,3-propanetriyl ester, } \\
\text { Piperidine, 3-(bromomethyl)-ester }\end{array}$ & $\begin{array}{l}51.916 \%- \\
100.00 \%\end{array}$ & - & - \\
\hline
\end{tabular}

Ogundipe and Akinrinlade, 1998; Kadiri, 2003; Kadiri and Olowokudejo, 2016). Characteristically, the quantitative data overlap significantly among the one hundred individuals investigated thus providing the value range of the data upon which the species can be defined or differentiated from another related species. Environmental factors have been implicated in influencing the expression of morphological characters both quantitatively and qualitatively (Stace, 1965).

Icacina trichantha incorporates interesting character constituents in line with Otun et al. (2015) who reported the presence of tannin, flavonoid, glycoside, terpenoid and steroid in hexane extract and the absence of saponin. These chemicals underlie their medicinal value. Phytochemicals are responsible for the biological activities of plants. Flavonoids are hydroxylated phenolic compounds known to be synthesized as a defense against microbial infection (Kumar and Pandey, 2013); concequently they exhibit pharmacological potentials such as: antimicrobial, cytotoxicity, anti-inflammatory and antitumor properties. Tannins have the ability to bind protein and metal ions from solution, hence, its benefit in the prevention of cancer activity and treatment of 
inflammatory conditions (Olajide et al., 2004, Okuda and Ito, 2011; Otun et al., 2015).

The GC-MS results of hexane leaf extracts of I. trichantha revealed the abundant presence of an ester 9Octadecadienoic acid which have been reported to exhibit antiinflammatory and antiarthritic property (Lalitha Rani et al., 2009). It may also be useful as anti-cancer, hepatoprotective, nematicide, insectifuge, anti-histaminic, anticoronary, anti-eczemic, anti-acne, 5-alpha reductase inhibitor and anti-androgenic agent (Vohra and Kaur, 2011). In addition, dodecanoic acid was also detected in both leaf and root hexane extracts and its antifungal activity has been reported which may attribute its use as an antimicrobial agent (Jagtap et al., 2009). Therefore, the chemical diversity in $I$. trichantha alludes to its quintessential medicinal uses in the folkloric health care system.

However, the information provided from the morphological and chemical assessment of the plant appears to be helpful in identifying and characterizing the species, and they would assist in crude drug research of the plant.

\section{Acknowledgments}

The authors are grateful to the local people of the commuities where the plant materials were collected and Dr. (Mrs.) Ugbogu, Head of the herbarium of Forestry Research Institute, Ibadan, Nigeria for granting access to herbarium infrastructure and nomenclatural authentication.

\section{References}

Agyakwa CW, Akobundu OI (1998). A handbook of West African weeds $2^{\text {nd }}$ ed. Nigeria: International Institute for Tropical Agriculture.

Ajayi GO, Kadiri AB, Egbedi ME and Oyeyemi OO (2011). Pharmacognostic study of two medicinal species of Rytigynia (Rubiaceae) from Nigeria. Phytologia Balcanica 17(3): 355-359.

Alawode TT, Lajide L, Owolabi BJ, Olaleye MT (2018). Investigation into the antioxidant and in vitro anti-inflammatory use of the leaves and tuber extracts of Icacina trichantha. Journal of Chemical Society of Nigeria 43(4): 699-706.

Asuzu IU, Aforonwa CU (2008). The pharmacological effects of Icacina trichantha leaf methanol extract. Journal of Herbs, Spices and Medicinal Plants 6(1): 1998-2006.

Asuzu IU, Abubakar II (1995a). The effects of Icacina trichantha tuber extract on the nervous system. Phytotherapy Research 9: 21-25.

Asuzu IU, Abubakar II (1995b). The antihepatotoxic and antinephrotoxic activities of lcacina trichantha tuber extract. Journal of Herbs Spices and Medicinal Plants 3: 9-20.

Burkhill HM (1985). The Useful Plants of West Tropical Africa. 2nd ed. Kew, UK: Royal Botanic Gardens.

Che CT, Zhao M, Guo B, Onakpa MM (2016). Icacina trichantha, A tropical medicinal plant. Nat Prod Commun. 11(7): 10391042.

Dalziel JM, (1937). The useful plants of west tropical Africa. London: Crown Overseas Agents for the Colonies.

Davis PH, Heywood VH (1963). Principles of angiosperm taxonomy. Edinburgh: Oliver \& Boyd. Ltd.

Harborne JB (1991). Phytochemical Methods. London: Chapman and Hall.

Hassler M (2020). World Plants: World Plants: Synonymic checklists of the vascular plants of the world. In Species 2000 \& ITIS Catalogue of Life, 2020-02-24.

Holmgren P, Holmgren N (2003). Index Herbariorum http://www.nybg.org/bsci/ih/ih.html / [accessed 15 June 2020].

Hutchinson J, Dalziel JM (1958). Flora of west tropical Africa. London: Crown Agents of Overseas Governments and Administrations.

Jagtap NS, Khadabadi SS, Ghorpade DS, Banarase NB, Naphade SS (2009). Antimicrobial and antifungal activity of Centella asiatica (L.) Urban (Umbeliferae. Research Journal of Pharmaceutical Technology 2: 328-30.

Kadiri AB (2003). Foliar epidermal morphology of the medicinal genus Momordica Linn, $\quad$ (Cucurbitaceae) in Nigeria. Nigerian Journal of Science 37(1): 25-33.

Kadiri AB, Olowokudejo JD (2016): Systematic significance of foliar epidermis and tendril morphology in three West African genera of Cucurbitaceae: Momordica L., Luffa Mill. and Trichosanthes L. Webbia-Journal of Plant Taxonomy and Geography 71(1): 91-105.

Kumar S, Pandey AK (2013). Chemistry and biological activities of flavonoids: an overview. The Scientific World Journal 162750: 1-17.

Lalitha Rani S, Mohan VR, Regini GS, Kalidass C (2009). GC-MS analysis of ethanolic extract of Pothos scandens leaf. Journal of Herbal Medicine Toxicology 3: 159-160.

Ogundipe OT, Akinrinlade OO (1998). Epidermal micromorphology of some species of Albizia Durazz (Mimosaceae). Phytomorphology 48: 27-323.

Okuda T, Ito H (2011). Tannins of constant structure in medicinal and food plants hydrolyzable tannins and polyphenols related to tannins. Molecules 16(3): 2191-2217.

Olajide OA, Aderogba MA, Adedapo ADA, Makinde JM (2004). Effects of Anacardium occidentale stem bark extract on in vivo inflammatory models. Journal of Ethnopharmacology 95: 139-142. 
Onakpa MM, Asuzu IU (2013). Histological changes and antidiabetic activities of Icacina trichantha tuber extract in beta-cells of alloxan induced diabetic rats. Asian Pacific Journal of Tropical Biomedicine 3(8): 628-633.

Onakpa MM, Ming Z, Tanja G, Wei-Lun C, Chun-Tao C, Santarsiero BD, Swanson S, Asuzu IU (2014). Cytotoxic (9 $\beta$ H)Pimarane and $(9 \beta \mathrm{H})-17-$ Norpimarane Diterpenes from the tuber of Icacina trichantha. Chemistry and Biodiversity 11: 1914-1922.

Otun KO, Onikosi DB, Ajiboye AA, Jimoh AA (2015). Chemical composition, antioxidant and antimicrobial potentials of Icacina trichantha Oliv. leaf extracts. Natural Product Chemical Research 10: 21-29.

Sofowora A (1993). Medicinal plants and traditional medicine in Africa. Nigeria: Spectrum Books Limited.

Stace CA (1965). The significance of leaf epidermis in the taxonomy of the Combretaceae; a general review of tribal, generic and specific characters . Botanical Journal of The Linnean Society 59: 229-252.

Trease GE, Evans WC (1998): A textbook of pharmacognosy. UK: W. B. Saunders Company Limited.

Vohra A, Kaur H (2011). Chemical investigation of medicinal plant Ajuga bracteosa. Journal of Natural Product Plant Resources 1(1): $37-45$. 